\title{
RHEUMATIC FEVER AS A FAMILIAL DISEASE. ENVIRONMENT, COMMUNICABILITY AND HEREDITY IN THEIR RELATION \\ TO THE OBSERVED FAMILIAL INCIDENCE OF THE DISEASE ${ }^{1,2}$
}

\author{
By MAY G. WILSON AND MORTON D. SCHWEITZER \\ (From the New York Hospital, and the Department of Pediatrics, Cornell University \\ Medical College, New York City)
}

(Received for publication February 1, 1937)

The concentration of rheumatic fever in certain families, particularly the frequent occurrence of multiple cases in the same household, has long been recognized. The reported familial incidence of rheumatic fever, based on clinical studies, ranges from 15 to 58 per cent. Three factors have been implicated in the observed familial incidence of this disease. First, common environmental conditions; second, communicability ; and third, susceptibility, probably on an hereditary basis. Up to the present time, conclusive evidence establishing any one or all of these hypotheses has not been presented.

It is believed that rheumatic fever has its highest incidence in urban populations of the north temperate zone. It also occurs in other sections of the world, particularly in localities where there are wide fluctuations in temperature. The disease appears to be more prevalent among the poorer classes of society, although not necessarily the poorest. The existence of unfavorable environmental conditions such as overcrowding, insufficient food and clothing, and frequent respiratory infections, are believed to be influential factors in the high familial incidence of the disease among the children of the poor. It does not, however, explain satisfactorily the occurrence of this disease in families of the well-to-do $(1,2,3$, 4,5 ).

The simultaneous occurrence of rheumatic fever in several members of a family group has been reported. Epidemics of rheumatic fever have been described in barracks, boarding schools, convalescent homes, and hospital wards. These observations suggest that rheumatic fever may spread by intimate contact. It is generally be-

1 Presented before the Cornell Research Society, March 8, 1937.

2 This study was conducted under a special grant from the Commonwealth Fund. lieved that rheumatic fever is an infection exhibiting a low degree of contagiousness, in that not every exposed person contracts the disease. Paul (1) suggests that the disease spreads from one member of the household to another during, and in association with, respiratory infections.

Recently, emphasis is being placed by many observers on a peculiar susceptibility of the host to the disease. The identification of the susceptible or resistant individual is not possible by any known serological or cutaneous tests. IrvineJones (6) states that simultaneous attacks may be explained "by some nonspecific but infective agent attacking several people of like 'rheumatic' constitution." Draper ( 7 ) has suggested that rheumatic susceptibility may be a sex-linked character. It is of interest to note that Cheadle (8), in 1889 , pointed out and emphasized that the tendency to rheumatism is transmitted, and many later observers have studied the hereditary transmission of the disease. A review of the literature, however, does not disclose adequate genetic analysis of sufficient data in conclusive support of this conception $(9,10)$.

The opportunity of observing a large number of rheumatic families over a period of years offered data which seemed suitable for an appraisal of the rôle of environment, contagion and heredity in their relation to the observed familial incidence of the disease. Material selected for study comprised 112 rheumatic families from the Children's Cardiac Clinic. Selection was based solely on residence in the lower and upper west and east sides of New York City, districts which could be adequately covered by two trained workers. These families, comprising 468 children over three years of age, equally divided as to sex, were under our observation from 3 to 18 years, an average of 9 years.

During the years 1933 to 1937 , the homes were 
TABLE I

Age and sex distribution of siblings in 112 families

\begin{tabular}{|c|c|c|c|c|c|c|c|c|c|c|}
\hline \multirow{3}{*}{ 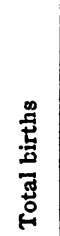 } & \multicolumn{2}{|c|}{$\begin{array}{c}\text { Under } \\
3 \text { years }\end{array}$} & \multicolumn{4}{|c|}{ Siblings } & \multicolumn{4}{|c|}{ Sex distribution } \\
\hline & \multirow[b]{2}{*}{$\begin{array}{l}\text { 尹ँ } \\
\text { ด̆ }\end{array}$} & \multirow{2}{*}{ 胥 } & \multicolumn{2}{|c|}{4 to 6 years } & \multicolumn{2}{|c|}{$\begin{array}{l}7 \text { to } 15 \text { years } \\
\text { and over }\end{array}$} & \multicolumn{2}{|c|}{$\begin{array}{l}\text { Total } \\
\text { siblings }\end{array}$} & \multicolumn{2}{|c|}{$\begin{array}{l}\text { Rheumatic } \\
\text { siblings }\end{array}$} \\
\hline & & & $\begin{array}{l}\text { Rheu- } \\
\text { matic }\end{array}$ & $\begin{array}{l}\text { Nor- } \\
\text { mal }\end{array}$ & $\begin{array}{l}\text { Rheu- } \\
\text { matic }\end{array}$ & $\begin{array}{l}\text { Nor- } \\
\text { mal }\end{array}$ & M. & F. & M. & F. \\
\hline \multirow[t]{2}{*}{509} & 19 & 22 & 8 & 43 & 219 & 198 & 240 & 228 & 104 & 123 \\
\hline & & & \multicolumn{4}{|c|}{$\begin{array}{l}\text { Total } 468 \\
\text { Total rheumatics } 227\end{array}$} & $\begin{array}{c}51 \\
\text { per } \\
\text { cent }\end{array}$ & $\begin{array}{c}49 \\
\text { per } \\
\text { cent }\end{array}$ & $\begin{array}{r}46 \\
\text { per } \\
\text { cent }\end{array}$ & $\begin{array}{c}54 \\
\text { per } \\
\text { cent }\end{array}$ \\
\hline
\end{tabular}

under very close observation; visits were made weekly or semi-monthly. A family record was kept of the onset and termination of every illness of each member of the household, including all respiratory infections. The environmental conditions in the homes were noted, i.e., available budget, size of the family, number of rooms, light, heat, dampness, food habits, clothing, and maternal care. With few exceptions, physical and fluoroscopic examinations were made of every member of the family at the Clinic. ${ }^{3}$ In some instances, death certificates, hospital records and statements from physicians were accepted. An historical pedigree of each family was obtained as accurately as was possible. The diagnosis of rheumatic fever, active or inactive, and of rheumatic heart disease, was made according to the criteria of the Heart Committee of the New York Tuberculosis and Health Association, Inc. (11).

The family was taken as the unit for study and a graphic record was kept for each family (Figure 2), similar to that used by McPhedran and Opie (12) in their studies on tuberculosis in families.

\section{Environmental factors in their relation to the familial incidence of rheumatic fever}

The families studied were of varying economic levels-ranging from dire poverty to middle class comfort. Rheumatic families from the higher income brackets were not represented in this series.

${ }^{8} \mathrm{We}$ wish to acknowledge our indebtedness to Dr. E. Ingerman, Dr. R. O. DuBois, Dr. B. McL. Spock, Dr. Betty Huse, C. Lingg, R. Johnstone, L. Ward, and E. Colt for their cooperation in these studies.
The wage earners in 77 per cent of the families were unskilled laborers; in 23 per cent of the families they were white collar workers.

From close observation of the existing home conditions it was determined that in about onethird of the families, Group 1, there was an adequate budget, food was sufficient in quantity and well balanced, rooms were dry and sunny, clothing was ample and maternal care sensible. In the remaining two-thirds, comprising Groups 2, 3, and 4 , certain conditions were observed which could be considered as possible predisposing factors to the disease. In Group 2 (13 per cent), rooms were dark and damp, and clothing was inadequate. In Group 3 (30 per cent), the food was insufficient in quantity and poorly balanced. In Group 4 (24 per cent), rooms were dark and damp, clothing was inadequate, food was insufficient in quantity and poorly balanced, and maternal care was poor.

A comparative analysis of the incidence of rheumatic siblings in these four environmental groupings, reveals them to be remarkably comparable. In Group 1, the incidence was 53 per cent; in Group 2, it was 45 per cent ; in Group 3, it was 38 per cent; in Group 4, it was 54 per cent.

These findings parallel those reported from the London Hospitals (4), namely, that incidence of rheumatic siblings in Class A (comparable to Group 1) was 16 per cent; in Class B (com-

TABLE II

Relation of environment to incidence of rheumatic fever in 112 families *

\begin{tabular}{|c|c|c|c|c|c|c|c|c|c|c|}
\hline \multirow{3}{*}{$\begin{array}{c}\text { Parental } \\
\text { groupings }\end{array}$} & \multirow{2}{*}{\multicolumn{2}{|c|}{$\begin{array}{c}\text { Total } \\
\text { families }\end{array}$}} & \multicolumn{8}{|c|}{ Environmental groups $†$} \\
\hline & & & \multicolumn{2}{|c|}{ Group 1} & \multicolumn{2}{|c|}{ Group 2} & \multicolumn{2}{|c|}{ Group 3} & \multicolumn{2}{|c|}{ Group 4} \\
\hline & $\underset{\text { ber }}{\text { Num- }}$ & $\begin{array}{l}\text { Per } \\
\text { cent }\end{array}$ & $\underset{\text { ber }}{\text { Num- }}$ & $\begin{array}{l}\text { Per } \\
\text { cent }\end{array}$ & $\underset{\text { ber }}{\text { Num- }}$ & $\begin{array}{l}\text { Per } \\
\text { cent }\end{array}$ & $\underset{\text { ber }}{\text { Num- }}$ & $\begin{array}{l}\text { Per } \\
\text { cent }\end{array} \mid$ & $\underset{\text { ber }}{\text { Num- }}$ & $\begin{array}{l}\text { Per } \\
\text { cent }\end{array}$ \\
\hline $\begin{array}{c}\text { Parents }- \text {. } \\
\text { Mother }+ \text {. } \\
\text { Father }+. \\
M+\text { and } \\
\mathbf{F}+\ldots . .\end{array}$ & $\begin{array}{r}57 \\
36 \\
15 \\
4\end{array}$ & $\begin{array}{l}100 \\
100 \\
100 \\
100\end{array}$ & $\begin{array}{r}17 \\
15 \\
3 \\
2\end{array}$ & $\begin{array}{l}30 \\
42 \\
20 \\
50\end{array}$ & $\begin{array}{l}9 \\
3 \\
3\end{array}$ & $\begin{array}{r}15.7 \\
8.3 \\
20.0\end{array}$ & $\begin{array}{r}18 \\
10 \\
5\end{array}$ & $\begin{array}{l}31.5 \\
27.7 \\
33.3\end{array}$ & $\begin{array}{r}13 \\
8 \\
4 \\
2\end{array}$ & $\begin{array}{l}22.8 \\
22.0 \\
26.6 \\
50.0 \\
\end{array}$ \\
\hline Total..... & 112 & 100 & 37 & 33 & 15 & 13.4 & 33 & 29.4 & 27 & 24.1 \\
\hline
\end{tabular}

* Social economic status: Unskilled labor 77 per cent. White collar 23 per cent.

$\dagger$ Environmental Groups:

1 : Adequate budget, food sufficient and well balanced, dry sunny rooms, ample clothing, sensible maternal care.

2: Rooms dark and damp, clothing inadequate.

3: Insufficient food, poorly balanced.

4: Rooms dark and damp, clothing inadequate, insufficient food, poorly balanced, maternal care poor. 
TABLE III

Incidence of rheumatic siblings in relation to environment and heredity

\begin{tabular}{|c|c|c|c|c|c|c|c|c|c|c|c|c|c|}
\hline \multirow{4}{*}{$\begin{array}{l}\text { Parental } \\
\text { group }\end{array}$} & \multirow{4}{*}{$\begin{array}{l}\text { Total } \\
\text { num- } \\
\text { ber } \\
\text { of } \\
\text { fam- } \\
\text { ilies }\end{array}$} & \multicolumn{12}{|c|}{ Environmental status } \\
\hline & & \multicolumn{3}{|c|}{ Favorable } & \multicolumn{9}{|c|}{ Unfavorable } \\
\hline & & \multicolumn{3}{|c|}{ Group 1} & \multicolumn{3}{|c|}{ Group 2} & \multicolumn{3}{|c|}{ Group 3} & \multicolumn{3}{|c|}{ Group 4} \\
\hline & & T. 8. & \multicolumn{2}{|c|}{ R. S. } & T.S. & \multicolumn{2}{|c|}{ R. 8 . } & T.S. & \multicolumn{2}{|c|}{ R. $\mathbf{8}$. } & T.S. & \multicolumn{2}{|c|}{ R. S. } \\
\hline Parents -... & 57 & 70 & 29 & $\begin{array}{l}\text { per } \\
\text { cent } \\
41.4\end{array}$ & 30 & 11 & $\begin{array}{l}\text { per } \\
\text { cent } \\
36.6\end{array}$ & 77 & 28 & \begin{tabular}{|c|} 
per \\
cent \\
36.3
\end{tabular} & 63 & 25 & $\begin{array}{l}\text { per } \\
\text { cent } \\
39.0\end{array}$ \\
\hline $\begin{array}{l}\text { Mother }+. . \\
\text { Father }+. . . \\
M+\text { and } F\end{array}$ & $\begin{array}{r}36 \\
15 \\
4\end{array}$ & $\begin{array}{r}51 \\
20 \\
7\end{array}$ & $\begin{array}{r}34 \\
10 \\
6\end{array}$ & $\begin{array}{l}66.6 \\
50.0 \\
85.7\end{array}$ & $\begin{array}{r}10 \\
7\end{array}$ & $\begin{array}{l}4 \\
6\end{array}$ & $\begin{array}{l}40.0 \\
85.7\end{array}$ & $\begin{array}{l}43 \\
16\end{array}$ & $\begin{array}{r}16 \\
8\end{array}$ & $\begin{array}{l}37.2 \\
50.0\end{array}$ & $\begin{array}{l}43 \\
20 \\
11\end{array}$ & $\begin{array}{r}29 \\
14 \\
7\end{array}$ & $\begin{array}{l}67.4 \\
70.0 \\
63.6\end{array}$ \\
\hline $\begin{array}{l}\text { Total } \\
\text { positive } \\
\text { families. .. }\end{array}$ & 55 & 78 & 50 & 64.1 & 17 & 10 & 58.8 & 59 & 24 & 40.6 & 74 & 50 & 67.5 \\
\hline \multirow[t]{2}{*}{$\begin{array}{l}\text { Total } \\
\text { families. . . }\end{array}$} & \multirow[t]{2}{*}{112} & \multirow[t]{2}{*}{148} & \multirow[t]{2}{*}{79} & \multirow[t]{2}{*}{53.3} & 47 & 21 & 44.6 & 136 & 52 & 38.2 & 137 & 75 & 54.0 \\
\hline & & & & & & & & & & 148 & $(46$. & & ent) \\
\hline
\end{tabular}

Key:

T. S.: Total siblings.

R. S.: Rheumatic siblings.

$(+)$ : Rheumatic, or positive.

(-): Non-rheumatic, or negative.

Pos. Fam.: Positive families, includes mother + , father + or both parents + .

parable to Groups 2 and 3), it was 12 per cent; and in Class C (comparable to Group 4), it was 10 per cent.

If the conditions concomitant with dire poverty were the determining factors influencing the familial incidence of the disease, one might have expected the highest incidence in Group 4 (our series) and Class $C$ (London Hospitals).

It is apparent from these observations that within the economic level represented by these families (which excludes families of the wellto-do), there was no direct relation between the incidence of rheumatic siblings and the environmental status.

A comparison of the incidence of rheumatic siblings in the various environmental classes, in relation to the presence of positive (rheumatic) parents, indicates that the incidence of rheumatic siblings is greater in each series with parental rheumatism (Figure 1). In Group 1, for example, where environmental conditions were favorable, the incidence of rheumatic siblings of negative (non-rheumatic) parents was 41 per cent, as compared with an incidence of 64 per cent within

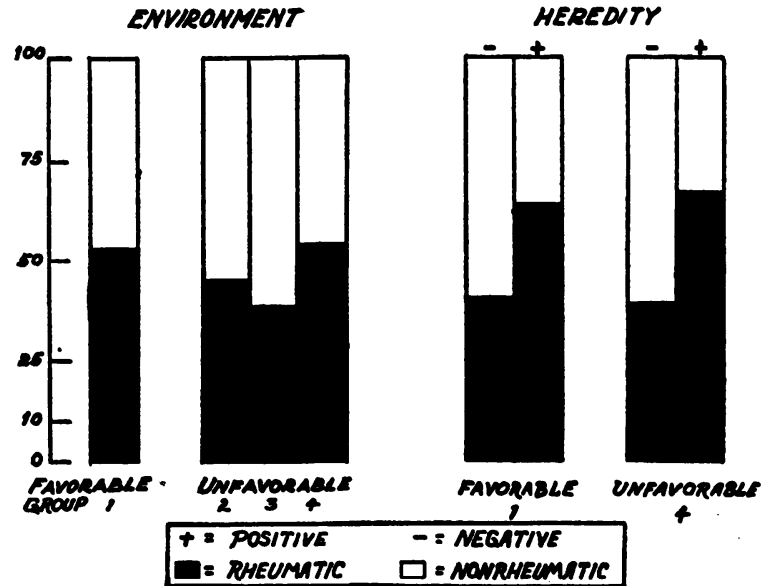

Fig. 1. Incidence of Rheumatic Siblings in Relation to Environment and HerEdity

the same environmental group but of rheumatic parents. Similarly, in Group 4, where unfavorable environmental conditions were present, the incidence was 39 per cent, compared with 67 per cent. A comparative analysis of the incidence of rheumatic siblings in relation to environment and to parental rheumatism in families of only four or five siblings, showed a similar trend.

\section{Comment}

In view of the high incidence of rheumatic fever among under-privileged children and the low incidence among children of the well-to-do, it might be expected that the familial incidence of the disease would be in direct relation to the type of environment. The data presented, however, reveals the incidence of rheumatic fever to be comparable in the various environmental groups studied. Comparative data on the familial incidence of rheumatic fever among rheumatic families of a higher economic level were not available for comparison. Should such studies reveal a low familial incidence it would indicate that some common environmental factor was operative in families of lower economic levels.

It is recognized, however, that unfavorable environmental conditions tend to increase the incidence of any infection. It cannot, therefore, be concluded that unfavorable environmental conditions are not contributing factors in this disease. However, the data presented would indicate that unfavorable environmental conditions are not the determining factor responsible for the observed 
familial incidence of the disease in this group. The significant increased incidence of rheumatic siblings that was observed in the series with parental rheumatism compared with the offspring of negative parents, admits of two interpretations: either that the parents may have been a source of exposure, or that heredity may be an important factor.

\section{Communicability of rheumatic fever in its rela- tion to the familial incidence of the disease}

If rheumatic fever is an infection which may be conveyed by contagion, its incidence to various types and sources of exposure may be determined. The method of procedure which seemed suitable for obtaining this information is similar to that used by Opie et al. in their studies on the spread of tuberculosis in families (12).

The family graph included the record of every member of the household starting from the year of birth of the oldest sibling through the year 1935. The average period of observation of these families was 9 years-ranging from 3 to 18 years. The onset and recurrence of rheumatic episodes (joint pains, polyarthritis, chorea, carditis and nodules) were recorded for every individual for each calendar year. Parental rheumatic activity occurring before the birth of the first sibling was not tabulated.

The biometric method utilized for the analysis was the "person year" method, that is, the unit was one person observed for one year.

To test the theory that rheumatic fever may be spread in families living in close contact, certain possible methods of spread were analyzed.

1. A rheumatic member of a family experiencing manifestations of rheumatic activity in any part of the calendar year might constitute a source of exposure to the rest of the household. This was arbitrarily termed a person year of "active exposure." (It may be argued that this method of analysis is not valid for the reason that contagiousness may exist only during the period of a preceding event such as a respiratory infection, the "primary phase" described by Coburn (13). However, since the person year unit would necessarily represent all rheumatic activity preceded by respiratory infections, it actually serves as a basis of estimating contagiousness no matter in what

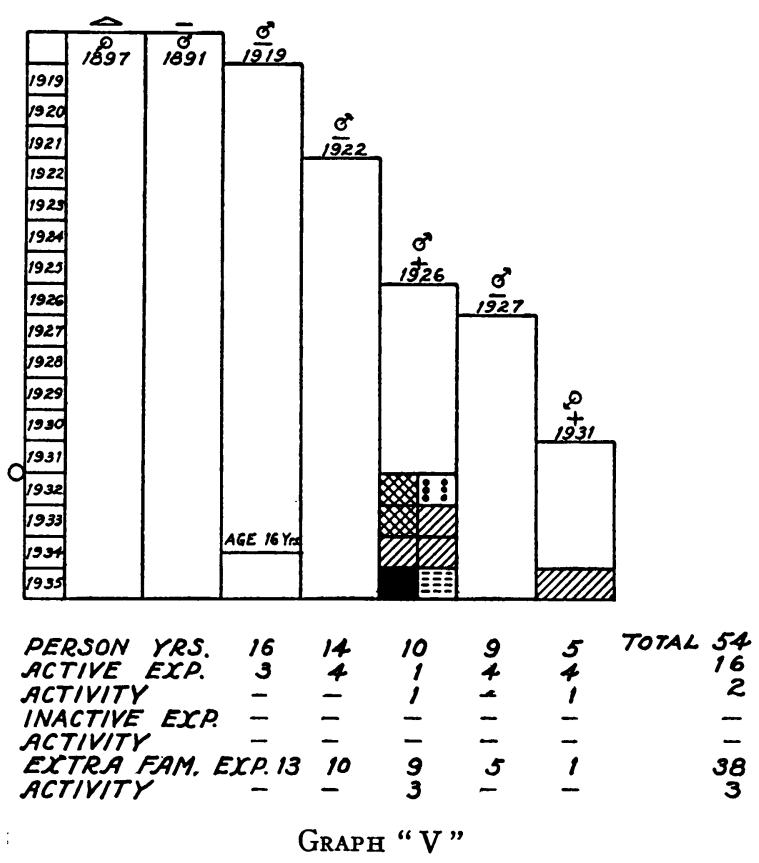

Fig. 2. Family Graph, "V" and " $\mathrm{L}$ "

Includes mother and father and 5 siblings. Parents negative although there was a history of rheumatism on maternal side (mother's sister had rheumatic heart disease).

Sibling 1 had a total of 16 person years, during 13 of which there was no exposure in the family. For 3 years there was "active exposure" to Sibling 3 , with no resulting activity.

Sibling 2 had a total of 14 person years, of which 10 years were years of "extra-familial exposure" and 4 were years of "active exposure" ( 3 years to Sibling 3 and 1 year to both Sibling 3 and Sibling 5) with no resulting activity.

Sibling 3 (Primary rheumatic in family-onset 1932) had a total of 10 person years, of which 9 were years of no exposure within the family. Patient manifested rheumatic activity after 6 years of "extra-familial exposure," resulting in 3 years of rheumatic activity. The 4th year of activity was simultaneous with activity in Sibling 5, and was considered a year of "active exposure" to Sibling 5.

Sibling 4 had a total of 9 person years, 5 of which were years of no familial exposure and 4 were years of "active exposure" ( 3 to Sibling 3 and 1 to Siblings 3 and 5), with no resulting activity.

Sibling 5 had a total of 5 person years. There was one year of "extra-familial exposure" and 4 years of "active exposure" to Sibling 3. After 3 years of "active exposure" to Sibling 3, patient developed rheumatic activity during the 4th year of exposure. The manifestation was "joint pains" which occurred during the same year as carditis and nodules in Sibling 3 (after an interval of 3 months). 


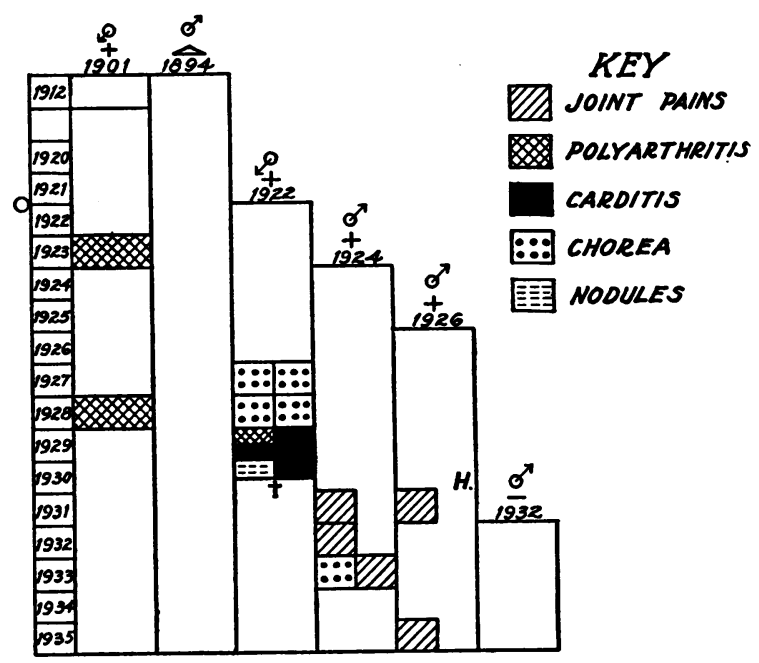

$\begin{array}{lrrrrrr}\text { PERSON YRS. } & 9 & 12 & 10 & 4 & \text { TOTAL } & 35 \\ \text { ACTIVE EXP. } & 2 & 6 & 7 & 3 & 18 \\ \text { ACTIVITY } & 1 & 1 & 1 & -1 & 3 \\ \text { INACTIVE EXP. } & 7 & 6 & 3 & 1 & 17 \\ \text { ACTIVITY } & 3 & 2 & 1 & - & 6\end{array}$

GRAPH “L”

Fig. 2. Family Graph, "V" and " $L$ "

Includes positive mother, negative father (whose sister had chorea as child), 3 positive siblings and 1 negative sibling. Mother had polyarthritis and chorea in childhood. In 1923 and 1928, mother had polyarthritis. For two years she was a source of "active exposure" to the remainder of the family and for 14 years she was a source of " inactive exposure."

Sibling 1 had a total of 9 person years, dying of rheumatic carditis in 1930. Person years comprised 2 years of "active exposure" and 7 years of "inactive exposure." Total of 4 years of activity. Onset of rheumatism was 4 years after " active exposure" to mother. (Prior to "active exposure," there was 1 year of "inactive exposure" 1922.) Following the year of "active exposure" (1923) there were 3 years of "inactive exposure" before the onset in 1927. During 1928, activity was simultaneous with activity in the mother.

Sibling 2. Total of 12 person years, of which 6 were years of "active exposure" and 6 were years of "inactive exposure." Onset of rheumatism in 1931 was preceded by 3 years of "inactive exposure," followed by 4 years of "active exposure." Activity occurred one year after "active exposure" to Sibling 1 and simultaneously with activity in Sibling 3.

Sibling 3. Total of 10 person years, of which 7 were years of "active exposure" and 3 of "inactive exposure." Onset was preceded by 1 year of "inactive exposure" and 4 years of "active exposure," occurring during simultaneous year of activity in Sibling 2 .

Sibling 4. Total of 4 person years, three of which were years of "active exposure," resulting in no activity. One year was a year of "inactive exposure," resulting in no activity. period of rheumatic activity such contagiousness may exist. Respiratory infections occurring in December, with subsequent rheumatic activity in January, might conceivably be excluded. Checking on our data for 79 families for the calendar year of 1933 (14), we found only 3 rheumatic recurrences out of a total of 139 that would have been excluded in this way. If one were to assume further that every rheumatic episode has its contagious phase in a preceding respiratory infection, our maximum error from this same source is but 10 per cent for this year.)

2. Rheumatic individuals experiencing intercurrent years of apparent freedom from rheumatic activity, might still be a possible source of exposure. Such years were calculated as person years of "inactive exposure."

3 . The primary case in a family may be considered to have acquired the disease by casual contact outside the family. The years prior to the onset of rheumatic activity were arbitrarily termed person years of "extra-familial exposure."

The total person years of "active" and "inactive" exposure, as well as the total person years of "extra-familial exposure" in each family, were calculated for each member of the household. Since rheumatic activity manifests itself mainly in childhood (from 4 to 16 years of age), the data tabulated for analysis included only person years of children reaching the ages of 4 to 16 years. (The application of the method is illustrated in the two family graphs: Figure 2, "V" and "L.") The interval elapsing between exposure and onset of the disease was calculated for both "active" and "inactive" exposure. Where "inactive exposure" preceded "active exposure," both were noted. Individuals having simultaneous years of activity were arbitrarily considered to have exposed each other.

It was possible to obtain more accurate data on the time relationship between exposure and onset of activity by an analysis of the simultaneous years of activity in these families for a period of three calendar years, when the dates of onset and termination of each rheumatic episode were observed and recorded.

In Table IV is presented a comparative analysis of the incidence of rheumatic fever in the 112 families, in relation to the source and type of exposure. Here it may be seen that for 55 fam- 
TABLE IV

Incidence of rheumatic fever in its relation to source and type of exposure

\begin{tabular}{|c|c|c|c|c|c|c|c|c|c|c|}
\hline & \multicolumn{2}{|c|}{$\begin{array}{c}\text { Mother } \\
+\end{array}$} & \multicolumn{2}{|c|}{$\begin{array}{c}\text { Father } \\
+\end{array}$} & \multicolumn{2}{|c|}{$\underset{F+}{M_{+}+\text {and }}$} & \multicolumn{2}{|c|}{$\begin{array}{l}\text { Total + } \\
\text { parents }\end{array}$} & \multicolumn{2}{|r|}{$\begin{array}{l}\text { Total - } \\
\text { parents }\end{array}$} \\
\hline & $\underset{\text { ber }}{\text { Num- }}$ & $\begin{array}{l}\text { Per } \\
\text { cent }\end{array}$ & $\underset{\text { ber }}{\text { Num- }}$ & $\begin{array}{c}\text { Per } \\
\text { cent }\end{array}$ & $\underset{\text { ber }}{\text { Num- }}$ & $\begin{array}{c}\text { Per } \\
\text { cent }\end{array}$ & $\underset{\text { ber }}{\text { Num- }}$ & $\begin{array}{c}\text { Per } \\
\text { cent }\end{array}$ & $\underset{\text { ber }}{\text { Num- }}$ & $\begin{array}{l}\text { Per } \\
\text { cent }\end{array}$ \\
\hline $\begin{array}{l}\text { Number of families }(112) \ldots \ldots \ldots \ldots \ldots \ldots \ldots \ldots \\
\text { Number of siblings }(468) \ldots \ldots \ldots \ldots \ldots \ldots \ldots \\
\text { Number of rheumatic siblings }(227) \ldots \ldots \ldots \ldots \ldots\end{array}$ & $\begin{array}{r}36 \\
147 \\
83\end{array}$ & 56.4 & $\begin{array}{l}15 \\
63 \\
38\end{array}$ & 60.3 & $\begin{array}{r}4 \\
18 \\
13\end{array}$ & 72.2 & $\begin{array}{r}55 \\
228 \\
134\end{array}$ & 58.6 & $\begin{array}{r}57 \\
240 \\
93\end{array}$ & 38.7 \\
\hline 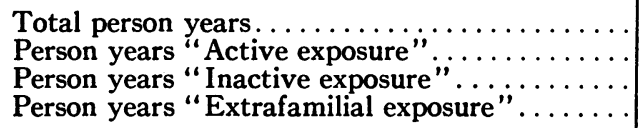 & $\begin{array}{r}1832 \\
598 \\
1234\end{array}$ & $\begin{array}{l}32.6 \\
67.3\end{array}$ & $\begin{array}{l}748 \\
284 \\
464\end{array}$ & \begin{tabular}{|l|}
38.0 \\
62.0
\end{tabular} & $\begin{array}{r}223 \\
86 \\
137\end{array}$ & $\begin{array}{l}38.5 \\
61.4\end{array}$ & $\begin{array}{r}2803 \\
968 \\
1835\end{array}$ & $\begin{array}{l}34.5 \\
65.4\end{array}$ & $\begin{array}{r}2955 \\
713 \\
569 \\
1673\end{array}$ & $\begin{array}{l}\begin{array}{l}24.0 \\
19.0\end{array} \\
57.0\end{array} 43$ \\
\hline 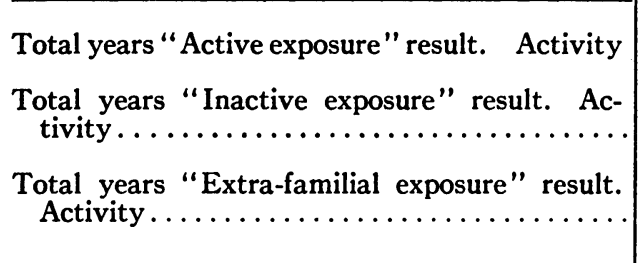 & 114 & 19.0 & 51 & 17.9 & 35 & 40.6 & 224 & 20.6 & $\begin{array}{c}\frac{90}{713} \\
\frac{60}{569} \\
196 \\
1673\end{array}$ & $\begin{array}{r}12.6\} \frac{150}{1282}=11.8 \\
\frac{196}{1673}=11.7\end{array}$ \\
\hline 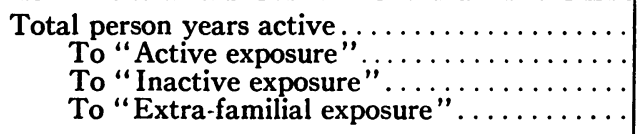 & $\begin{array}{l}270 \\
114 \\
156\end{array}$ & $\begin{array}{l}42.2 \\
57.7\end{array}$ & $\begin{array}{r}110 \\
51 \\
59\end{array}$ & \begin{tabular}{|}
46.3 \\
53.6
\end{tabular} & $\begin{array}{r}44 \\
35 \\
9\end{array}$ & $\begin{array}{l}79.5 \\
20.5\end{array}$ & $\begin{array}{l}424 \\
200 \\
224\end{array}$ & $\begin{array}{l}47.1 \\
52.8\end{array}$ & $\begin{array}{r}346 \\
90 \\
60 \\
196\end{array}$ & $\begin{array}{l}26.0 \\
17.3 \\
56.6\end{array}$ \\
\hline
\end{tabular}

ilies with parental rheumatism, giving an opportunity for familial exposure, of a total of 2,803 person years 35 per cent were years of "active exposure" and 65 per cent were years of "inactive exposure." It is of interest that only 21 per cent of the years of "active exposure" in these families could be considered to have resulted in rheumatic fever. One hundred and thirty-four rheumatic siblings experienced 424 person years of activity; 47 per cent of these years of activity occurring subsequent to "active exposure," and 53 per cent followed "inactive exposure." It is apparent that "active" and "inactive" exposure were equally effective.

In a comparison of the incidence of rheumatic fever in the $\mathbf{5 7}$ families with negative parents, an opportunity for comparing the relation of the incidence of rheumatic fever to the source of exposure (that is, familial or extra-familial) was offered. Of a total of 2,955 person years, 57 per cent were years of " extra-familial exposure," and 43 per cent were years of "familial exposure"

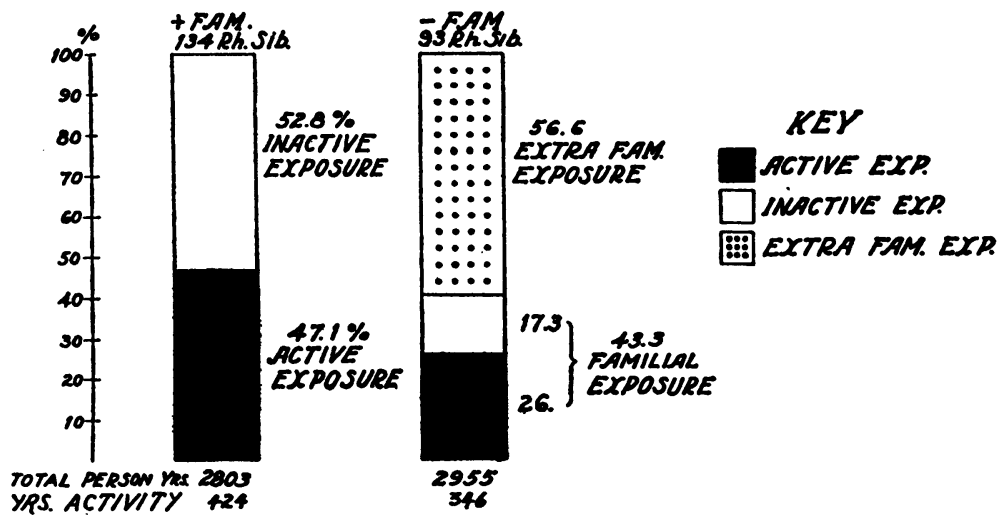

Fig. 3. Total Person Years of Activity Related to Source and Type OF Exposure 
(24 per cent of which were years of "active exposure," and 19 per cent "inactive exposure"). "Familial exposure" resulted in 11.8 per cent of activity, as compared with 11.7 per cent following " extra-familial exposure." Ninety-three rheumatic siblings experienced 346 person years of activity, of which about one-half ( 57 per cent) followed "extra-familial exposure" (Figure 3 ).

There is another method of demonstrating the relative influence of "extra-familial exposure" (Table V). In 53 of the families with negative

TABLE V

Frequency of primary and secondary rheumatic siblings of negative parents

\begin{tabular}{|c|c|c|c|}
\hline & Total & $\begin{array}{l}\text { Posi- } \\
\text { tive }\end{array}$ & $\begin{array}{l}\text { Percent- } \\
\text { age } \\
\text { positive }\end{array}$ \\
\hline 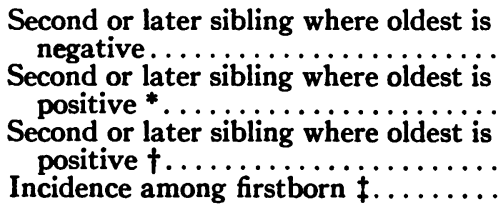 & $\begin{array}{l}48 \\
65 \\
35 \\
53\end{array}$ & $\begin{array}{l}20 \\
28 \\
16 \\
24\end{array}$ & $\begin{array}{l}42 \pm 7 \\
43 \pm 6 \\
46 \pm 8 \\
45 \pm 7\end{array}$ \\
\hline
\end{tabular}

* Including only those born before first sibling became positive.

† Including only those born after first sibling became positive.

‡ Excluding one sibling families, and those families where first sibling became positive after a later sibling was positive.

(non-rheumatic) parents, a division was made depending on whether the first child was negative or positive. Where the first child was negative, 42 per cent of 48 subsequent siblings were rheumatic. Where the first sibling was positive, 44 per cent of 100 subsequent siblings were rheumatic. The incidence of rheumatism among the firstborn, as given in the table, was 42 per cent. The relative incidence of rheumatic fever is, therefore, the same for primary and secondary cases in a family. These observations indicate that exposure was as effective from casual contact ("extra-familial exposure"), as it was by intimate contact within the family.

An attempt was made to determine the time relationship between the type of exposure and the onset of the disease. In Table VI it may be seen that in only 20 per cent was the onset of the disease within a year of "active exposure." In 49 per cent the onset was within 2 to 5 years, and in 31 per cent the onset was within 6 to 15 years.
TABLE VI

Interval between exposure and onset

\begin{tabular}{|c|c|c|c|c|}
\hline \multirow{2}{*}{$\begin{array}{l}\text { Interval between } \\
\text { familial exposure } \\
\text { and onset of rheu- } \\
\text { matic activity }\end{array}$} & \multicolumn{2}{|c|}{ Active exposure } & \multicolumn{2}{|c|}{ Inactive exposure } \\
\hline & Number & Per cent & Number & Per cent \\
\hline $\begin{array}{l}1 \text { year. ........... } \\
2 \text { to } 5 \text { years. . . . } \\
6 \text { to } 15 \text { years. . . }\end{array}$ & $\begin{array}{l}24 \\
58 \\
37\end{array}$ & $\begin{array}{l}20 \\
49 \\
31\end{array}$ & $\begin{array}{l}15 \\
63 \\
32\end{array}$ & $\begin{array}{l}14 \\
57 \\
29\end{array}$ \\
\hline
\end{tabular}

There was no significant difference in the time intervening between the onset of the disease after "active" and " inactive" exposure.

The occurrence of rheumatic activity in more than one member of a family during the same year suggests communicability of the disease. Of a total of 588 calendar years of activity, 159, or 27 per cent, were simultaneous years. The interval between exposure and onset of various types of rheumatic activity were observed and recorded. In Table VII, and Figures 4 and 5,

TABLE VII

Type of rheumatic manifestation and interval between simultaneous calendar years of activity *

\begin{tabular}{|c|c|c|c|c|c|c|c|c|}
\hline \multirow{3}{*}{ Related manifestations } & \multirow{2}{*}{\multicolumn{2}{|c|}{$\begin{array}{l}\text { Total } \\
\text { manifesta- } \\
\text { tions }\end{array}$}} & \multicolumn{6}{|c|}{ Interval } \\
\hline & & & \multicolumn{2}{|c|}{1 month } & \multicolumn{2}{|c|}{$\begin{array}{l}1 \text { to } 2 \\
\text { months }\end{array}$} & \multicolumn{2}{|c|}{$\begin{array}{l}2 \text { to } 11 \\
\text { months }\end{array}$} \\
\hline & Num- & $\begin{array}{l}\text { Per } \\
\text { cent }\end{array}$ & Num- & $\begin{array}{l}\text { Per } \\
\text { cent }\end{array}$ & Num- & $\begin{array}{l}\text { Per } \\
\text { cent }\end{array}$ & $\underset{\text { ber }}{\text { Num- }}$ & $\begin{array}{l}\text { Per } \\
\text { cent }\end{array}$ \\
\hline $\begin{array}{l}\text { Joint pains and joint pains } . . \\
\text { Joint pains and polyarthritis } \\
\text { or carditis............... } \\
\text { Joint pains and chorea...... }\end{array}$ & $\begin{array}{l}69 \\
47 \\
48\end{array}$ & $\begin{array}{l}33.0 \\
22.5 \\
23.0\end{array}$ & $\begin{array}{r}29 \\
16 \\
8\end{array}$ & $\begin{array}{l}42 \\
34 \\
16\end{array}$ & $\begin{array}{l}17 \\
12 \\
15\end{array}$ & $\begin{array}{l}24 \\
24 \\
31\end{array}$ & $\begin{array}{l}23 \\
19 \\
25\end{array}$ & $\begin{array}{l}34 \\
42 \\
53\end{array}$ \\
\hline $\begin{array}{l}\text { Polyarthritis, carditis and } \\
\text { chorea................. }\end{array}$ & 45 & 21.5 & 8 & 18 & 7 & 16 & 30 & 66 \\
\hline Total related manifestations. & 209 & 100 & 61 & 29.1 & 51 & 24.4 & 97 & 46.4 \\
\hline
\end{tabular}

* The onset and termination of every illness was recorded for 112 families over a period of three years.

it may be seen that in only 29 per cent was the interval one month; in 24 per cent it was 1 to 2 months; in 47 per cent it was 2 to 11 months. Approximately three-fourths of the related manifestations were between joint pains and some other manifestation of the disease, and in only one-fourth were related major manifestations, i.e., polyarthritis, carditis and chorea. In this group, in 66 per cent the interval between exposure and activity was 2 to 11 months.

It is of interest that in $\mathbf{5 1}$ families, 59 parents (mother or father) were rheumatic; 27 , or 44 
per cent, of the parents experienced rheumatic activity during the lifetime of the siblings. In no instance did a negative parent acquire the disease. the household respiratory infections could be related to recurrence of rheumatic activity. Rheumatic children experienced more frequent respiratory infections than non-rheumatic children in

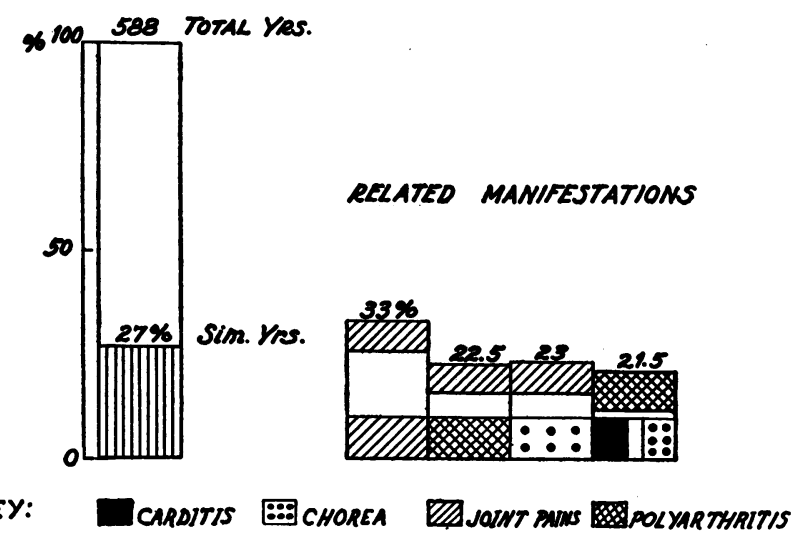

Fig. 4. Simultaneous Years of Activity

The average age of onset of rheumatic fever in the negative and positive families was 7 years of age; the earliest age of onset was 2 years. During the period of observation, of 123 nonrheumatic siblings ranging in age from 15 to 30 years, no brother or sister negative to the age of 15 years, subsequently acquired the disease.

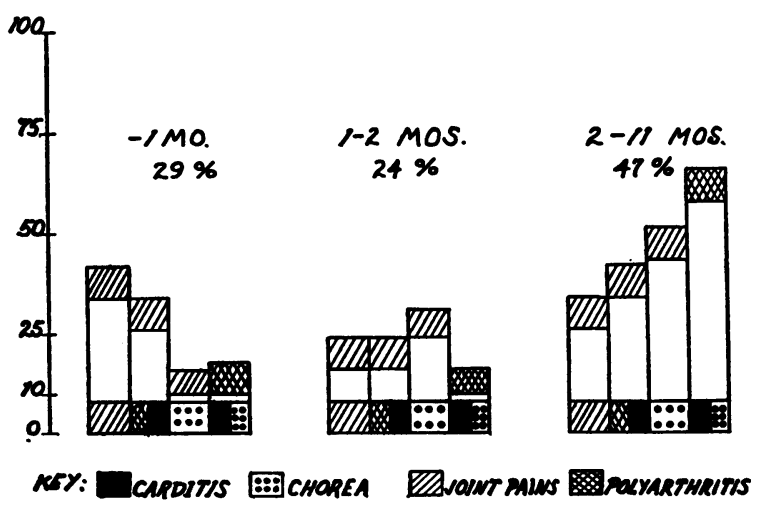

Fig. 5. Interval Between Associated ManifestaTIONS-Simultaneous Years

Studies on the relationship between respiratory infections and the occurrence of rheumatic fever in these families have been published (14). Continued close supervision of these families for the past two years confirmed the observations reported. The occurrence of respiratory infections in the families were not associated with the spread of rheumatic activity. Less than 15 per cent of these families. The majority of the respiratory infections occurred simultaneously with, during, or following rheumatic activity. During the periods 1930 to 1932 and 1933 to 1937 , respiratory infections were observed to precede only 10 to 25 per cent of rheumatic recurrences (within a period of 3 to 4 weeks). These observations do not indicate that there is a causal relationship between respiratory infections and the occurrence of rheumatic fever in the families studied. If rheumatic fever is communicable during a preceding or associated respiratory infection, there should have been a difference between the effectiveness of "active" and "inactive" exposure.

It is evident from the data presented that there is no direct relation between the type and source of exposure and the resulting disease. Some factor, other than intimate contact, must be primarily responsible for the observed familial incidence of the disease in these families.

\section{Comment}

It might be expected that if rheumatic fever is spread in the families by intimate contact, there would be evident a direct relation between "familial exposure" and infection. The data secured, however, indicate that there is no apparent relation between type and source of exposure and resulting disease. There was no significant difference in the incidence of the disease following "active" or "inactive" exposure. 
The incidence of the disease following intimate contact ("familial exposure") and casual contact (" extra-familial exposure") were comparable. Within the limits of our accuracy of clinical diagnosis and method of analysis utilized, it is evident that the duration of the interval between exposure and the onset of the disease is not like that of other contagious diseases. A consideration of all the data secured would indicate that if rheumatic fever is spread in families by contagion, the acquisition of the disease is primarily determined by some factor other than exposure to a rheumatic individual. That the factor may be one of hereditary susceptibility is suggested by the increased incidence of rheumatic siblings in series of subjects with parental rheumatism.

\section{Heredity in its relation to the observed familial incidence of rheumatic fever}

It has already been suggested that there is a direct relation between the incidence of rheumatic siblings and parental rheumatism. The reciprocal of this relation was also found to hold. Inquiry into the family pedigree of these patients disclosed that in $\mathbf{5 5}$ families one or both parents were rheumatic. In addition, in 29 families, or 53 per cent, of this group-grandparents, aunts, uncles or cousins were rheumatic. In 57 families both parents were negative, but of this group, 26 families (46 per cent) had rheumatic individuals on the maternal or paternal sides. In only $28 \mathrm{per}$ cent of the 112 families were we unable to obtain a definite history of rheumatism. These results suggest the operation of genetic factors.

The data adequate for genetic analysis included 122 families which had been examined in the Clinic. (Four of the 112 used in the preceding part of the paper were omitted, and twelve others added.) In addition, 273 consecutive cases of rheumatic patients from the pediatric cardiac clinic were used. The information on familial incidence was obtained from the clinic charts, on which this information was routinely recorded, and, unlike the 122 families intensively studied, it does not represent examination of all the members of the family. From the literature, additional data for analysis was obtained from the British Medical Research Council Report (3), and from Draper (7). Irvine-Jones' data on twins (6) were used.
The incidence of rheumatic fever among twins may also be used as a criterion of the importance of genetic factors in the familial incidence of this disease. It will be recalled that identical twins are descended from a single ovum and sperm, while fraternal twins are derived from two independent fertilized eggs. If genetic factors play a rôle in the occurrence of rheumatic fever, it would be expected that differences would be found between identical and fraternal twins. In our records there were seven pairs of twins, of which two pairs were identical. Dr. Irvine-Jones has published data on nine additional pairs. These are included in Table VIII. In this table,

TABLE VIII

Incidence of rheumatic fever in twins

\begin{tabular}{|c|c|c|c|c|c|c|c|c|}
\hline & \multicolumn{4}{|c|}{ Identical } & \multicolumn{4}{|c|}{ Fraternal } \\
\hline & \multirow{2}{*}{ Total } & \multicolumn{3}{|c|}{ Pairs } & \multirow{2}{*}{ Total } & \multicolumn{3}{|c|}{ Pairs } \\
\hline & & ++ & $--\mid$ & +- & & ++ & $--\mid$ & + \\
\hline $\begin{array}{l}\text { Original data.... } \\
\text { Irvine-Jones ( } 7)\end{array}$ & $\begin{array}{l}2 \\
2\end{array}$ & $\begin{array}{l}2 \\
2\end{array}$ & $\begin{array}{l}0 \\
0\end{array}$ & $\begin{array}{l}0 \\
0\end{array}$ & $\begin{array}{l}5 \\
7\end{array}$ & $\begin{array}{l}2 \\
0\end{array}$ & $\begin{array}{l}1 \\
2\end{array}$ & $\begin{array}{l}2 \\
5\end{array}$ \\
\hline Total...... & 4 & 4 & & & 12 & 2 & 3 & 7 \\
\hline
\end{tabular}

of the four sets of identical twins, all four are alike in having rheumatic fever. Of the twelve pairs of fraternal twins, five are similar (that is, either both have rheumatic fever or both are free from it) and seven pairs are dissimilar. Inasmuch as the environmental features associated with all twins are usually comparable, it is diffcult to explain this different incidence in fraternal and identical twins. They are, however, fully consistent with a genetic interpretation which requires that identical twins be similar, while fraternal twins would not be expected to be any more alike than any two siblings.

Recent progress in genetic science has made it possible to approach problems of human heredity in relation to disease with greater precision than has hitherto been possible.

In the application of Mendelian formulae to data on human heredity, it is necessary to introduce certain corrections for the inadvertent selection inherent in the original data. It will be recalled that the families selected for study were drawn from the children in attendance at the 
TABLE IX

Comparison of observed incidence of rheumatic siblings with expectation from Mendelian formulae

\begin{tabular}{|c|c|c|c|c|c|c|}
\hline $\begin{array}{l}\text { Num- } \\
\text { ber } \\
\text { of } \\
\text { giblings } \\
\text { in each } \\
\text { family }\end{array}$ & $\begin{array}{c}\text { Number } \\
\text { of } \\
\text { families }\end{array}$ & $\begin{array}{c}\text { Ob- } \\
\text { served } \\
\text { number } \\
\text { of rheu- } \\
\text { matic } \\
\text { siblings }\end{array}$ & $\begin{array}{c}\text { Ex- } \\
\text { pected } \\
\text { number } \\
\text { of rheu- } \\
\text { matic } \\
\text { siblings }\end{array}$ & $\begin{array}{l}\text { Differ- } \\
\text { ence }\end{array}$ & $\sigma^{2}$ & $\begin{array}{l}\text { Differ- } \\
\text { ence/o }\end{array}$ \\
\hline
\end{tabular}

A. Negative female $\times$ NEgative Male

\begin{tabular}{r|r|r|r|r|r|r}
\hline 1 & 1 & 1 & 1 & & & \\
2 & 11 & 12 & 12.6 & 0.6 & 1.35 & 0.5 \\
3 & 12 & 17 & 15.6 & 1.4 & 3.16 & 0.8 \\
4 & 13 & 21 & 19.0 & 2.0 & 5.42 & 0.9 \\
5 & 9 & 17 & 14.7 & 2.3 & 5.32 & 1.0 \\
6 & 4 & 10 & 7.3 & 2.7 & 3.00 & 1.6 \\
7 & 3 & 9 & 6.1 & 2.9 & 2.91 & 1.7 \\
8 & 3 & 5 & 6.7 & 1.7 & 3.54 & 0.9 \\
9 & 1 & 1 & 2.4 & 1.4 & 1.38 & 1.2 \\
10 & 1 & 1 & 2.6 & 1.6 & 1.59 & 1.3 \\
\hline Total & 58 & 94 & 88.0 & & 27.72 & \\
\cline { 2 - 5 } & & & & $1.1 \sigma$ & $=5.25$ & \\
\hline
\end{tabular}

B. POSitive female $\times$ Negative male

\begin{tabular}{c|r|r|r|r|r|r}
\hline \hline 1 & 2 & 2 & 2 & & & \\
2 & 6 & 10 & 8 & 2 & 1.31 & 1.7 \\
3 & 8 & 14 & 13.7 & 0.3 & 3.91 & 0.2 \\
4 & 7 & 16 & 14.9 & 1.1 & 5.48 & 0.5 \\
5 & 3 & 7 & 7.7 & 0.7 & 3.24 & 0.4 \\
6 & 4 & 11 & 12.2 & 1.2 & 5.52 & 0.5 \\
7 & 3 & 11 & 10.6 & 0.4 & 5.00 & 0.2 \\
8 & 3 & 14 & 12.0 & 2.0 & 5.83 & 0.8 \\
9 & 1 & 5 & 4.5 & 0.5 & 2.22 & 0.3 \\
\hline Total & 37 & 90 & 85.6 & & 32.51 & \\
& & & & $0.7 \sigma$ & $=5.8$ & \\
\hline
\end{tabular}

C. NEgATIVE FEMALE $\times$ POSITIVE MALE

\begin{tabular}{|c|c|c|c|c|c|c|}
\hline $\begin{array}{l}1 \\
2 \\
3 \\
4 \\
5 \\
6 \\
7 \\
8 \\
9\end{array}$ & $\begin{array}{l}1 \\
2 \\
3 \\
3 \\
2 \\
1\end{array}$ & $\begin{array}{l}1 \\
2 \\
6 \\
7 \\
6 \\
1 \\
6\end{array}$ & $\begin{array}{l}1 \\
2.7 \\
5.1 \\
6.4 \\
5.2 \\
3.0\end{array}$ & $\begin{array}{l}0.7 \\
0.9 \\
0.6 \\
0.8 \\
2.0\end{array}$ & $\begin{array}{l}0.44 \\
1.47 \\
2.34 \\
2.16 \\
1.38 \\
\\
2.22\end{array}$ & $\begin{array}{l}1.0 \\
0.7 \\
2.5 \\
1.8 \\
0.6 \\
\\
1.0\end{array}$ \\
\hline \multirow[t]{2}{*}{ Total } & 13 & 29 & 27.9 & & 10.01 & \\
\hline & & & & $0.3 \sigma$ & $=3.2$ & \\
\hline
\end{tabular}

Cardiac Clinic. Consequently, every family in the group contained at least one rheumatic child. Since this would not be true of a random sample of the population, a correction has to be introduced. It may be noted here that the correction must be made separately for each size of family. The details of the statistical method have recently been reviewed by Hogben (15) and Levit (16).

There is presented in Table IX $(A, B$, and $C)$, a comparison of the observed and expected values for each family of similar size. In crosses of $\mathbf{5 8}$ families of negative parents, the observed incidence was 94 , compared with an expected value of 88 . For 37 families with positive mothers and for 13 families with positive fathers, the observed and expected were respectively, 90 compared with 86 , and 29 compared with 27 . As shown in the table, the differences between observed and expected are clearly not statistically significant in any of these instances.

In analyzing the mechanism of inheritance involved in this disease, there are five major possibilities which will be considered: simple dominance; a single autosomal recessive; two or more recessive factors; two or more dominant factors ; and sex linkage.

Simple dominance. Any heredity character which is inherited as a simple dominant should be expressed in every generation of a line in which the factor is being transmitted. Inasmuch as 48 per cent of the 122 families have negative parents, this possibility may be excluded. The subsequent discussion of penetrance indicates that partial dominance may also be excluded.

Single recessive and two or more recessive genes. If more than one recessive gene are necessary for the expression of a given trait, the proportion of families with more than one member affected should be fewer the larger the number of factors involved (Hogben (15)). Table $\mathrm{X}$ shows the comparison of the observed inci-

TABLE $\mathbf{X}$

Comparison of observed incidence of families with more than one rheumatic sibling with expectation from single recessive and double recessive gene hypotheses

NEgATIVE FEMALE $\times$ NEgATIVE MALE

\begin{tabular}{c|c|c|c|c|c}
\hline \hline $\begin{array}{c}\text { Number } \\
\text { of } \\
\text { siblings } \\
\text { in each } \\
\text { family }\end{array}$ & $\begin{array}{c}\text { Number of } \\
\text { families }\end{array}$ & $\begin{array}{c}\text { Families } \\
\text { having } \\
\text { more } \\
\text { than 1+ }\end{array}$ & $\begin{array}{c}\text { Expected } \\
\text { double } \\
\text { recessive } \\
\text { hypothesis }\end{array}$ & Observed & $\begin{array}{c}\text { Expected } \\
\text { single } \\
\text { recessive } \\
\text { hypothesis }\end{array}$ \\
\hline & & 0 & per cent & per cent & per cent \\
1 & 1 & 0 & 0 & 0 \\
2 & 11 & 1 & 3 & 9 & 15 \\
3 & 12 & 4 & 6 & 33 & 27 \\
4 & 13 & 6 & 9 & 41 & 39 \\
5 & 9 & 7 & 13 & 78 & 48 \\
6 & 4 & 2 & 15 & 50 & 56 \\
7 & 3 & 2 & 18 & 67 & 64 \\
\hline
\end{tabular}


dence of multiple cases with the expected values if one or two recessive factors were involved. For the case of four siblings, the number expected for a single recessive case is 39 per cent; for a double recessive case it is 9 per cent. The actual value, 41 per cent, is in much closer agreement with the expectation for a single factor. The same agreement with single factor requirements also holds for all other sizes of families. Predictions for three and four recessive factors were computed and found to be even less in agreement with the observations than is the two factor hypothesis.

Single recessive and two or three dominant genes. The analysis for the hypotheses of two, three or four dominant factors in comparison with a single recessive factor, gives different predicted values for each hypothesis.

The computations in Table XI permit the com-

TABLE XI

Comparison of observed incidence of rheumatism in families with expectation from single recessive, double dominant and triple dominant gene hypotheses

NEGATIVE FEMALE $\times$ NEgATIVE MALE

\begin{tabular}{c|c|r|r|r|r}
\hline \hline $\begin{array}{c}\text { Number } \\
\text { of } \\
\text { siblings } \\
\text { in each } \\
\text { family }\end{array}$ & $\begin{array}{c}\text { Number of } \\
\text { families }\end{array}$ & $\begin{array}{c}\text { Ob- } \\
\text { served } \\
\text { single }\end{array}$ & $\begin{array}{c}\text { Expected } \\
\text { single } \\
\text { recessive } \\
\text { hypothesis }\end{array}$ & $\begin{array}{c}\text { Expected } \\
\text { double } \\
\text { dominant } \\
\text { hypothesis }\end{array}$ & $\begin{array}{c}\text { Expected } \\
\text { triple } \\
\text { dominant } \\
\text { hypothesis }\end{array}$ \\
\hline 1 & 1 & 1 & 1 & 1 & 1 \\
2 & 6 & 6 & 7.8 & 6.4 & 6.2 \\
3 & 14 & 18 & 18.2 & 15.9 & 14.9 \\
4 & 13 & 18 & 19.0 & 15.7 & 14.3 \\
5 & 8 & 17 & 13.1 & 10.3 & 9.1 \\
6 & 3 & 6 & 5.5 & 4.1 & 4.5 \\
7 & 1 & 5 & 2.0 & 1.4 & 1.2 \\
8 & 3 & 5 & 6.7 & 4.6 & 3.7 \\
9 & 1 & 1 & 2.4 & 1.6 & 1.3 \\
\hline Total & 50 & 77 & 75.7 & 61.0 & 56.2 \\
\hline
\end{tabular}

parison between the incidence of rheumatic diseases observed in the progeny of negative parents, with the values predicted from a single recessive gene, and from two dominant or three dominant genes. The observed frequency, 77 , is in closer agreement with the predicted value from one recessive gene 75.7; than it is with two dominant genes 61.0; or three dominant genes 56.2. Computations for more than three dominant factors were still more divergent from the observations.

Sex linkage. A test for sex linkage was also made. Among the progeny of positive mothers by negative fathers, 58 per cent of 71 daughters were positive and 51 per cent of 78 sons were positive. If sex linkage were involved, no positive daughters should occur in this series, and 50 per cent of the sons should be positive. The possibility of sex linkage is, therefore, excluded. These data are fully consistent with the conclusion that the hereditary mechanism involved is a single autosomal recessive gene.

In order to test the universality of these results, analyses were made of three additional sets of data, as follows: $\mathbf{2 7 3}$ families of the children in attendance at the Pediatric Cardiac Clinic (the family incidence based on histories) ; 129 family trees of negative parents published in the British Medical Research Council Report (3); and 50 family trees collected by Draper (7).

In each of the three sets of data the incidence among siblings of negative parents was lower than the incidence where one parent was positive. When both parents were positive the family incidence was still higher. In Table XII is presented

TABLE XII

Comparison of observed incidence with expectation from Mendelian formulae *

\begin{tabular}{|c|c|c|c|c|c|c|}
\hline $\begin{array}{l}\text { Name of } \\
\text { hospital }\end{array}$ & $\begin{array}{c}\text { Num- } \\
\text { ber of } \\
\text { siblings } \\
\text { in } \\
\text { each } \\
\text { family }\end{array}$ & $\begin{array}{c}\text { Number } \\
\text { of } \\
\text { families }\end{array}$ & $\begin{array}{c}\text { Ob- } \\
\text { served } \\
\text { num- } \\
\text { ber }\end{array}$ & $\begin{array}{c}\text { Ex- } \\
\text { pected } \\
\text { num- } \\
\text { ber }\end{array}$ & $\begin{array}{l}\text { Differ- } \\
\text { ence }\end{array}$ & $\sigma^{2}$ \\
\hline \multirow[t]{3}{*}{$\begin{array}{l}\text { St. Thomas' } \\
\text { Hospital }\end{array}$} & $\begin{array}{l}1 \\
2 \\
3 \\
4 \\
5 \\
6 \\
7 \\
8 \\
9\end{array}$ & $\begin{array}{r}10 \\
19 \\
19 \\
9 \\
12 \\
5 \\
1 \\
2 \\
2\end{array}$ & $\begin{array}{r}10 \\
23 \\
21 \\
11 \\
17 \\
9 \\
2 \\
5 \\
3\end{array}$ & $\begin{array}{r}10 \\
21.7 \\
24.6 \\
12.2 \\
19.7 \\
11.0 \\
2.0 \\
4.4 \\
4.9\end{array}$ & $\begin{array}{l}1.3 \\
3.6 \\
1.2 \\
2.7 \\
2.0 \\
0 \\
0.6 \\
1.9\end{array}$ & $\begin{array}{l}2.33 \\
5.00 \\
3.78 \\
7.10 \\
3.88 \\
0.97 \\
2.35 \\
2.78\end{array}$ \\
\hline & \multirow[t]{2}{*}{ Total } & 79 & 101 & 110.5 & & 28.19 \\
\hline & & & & & $1.8 \sigma$ & $=5.3$ \\
\hline \multirow[t]{3}{*}{$\begin{array}{c}\text { Children's } \\
\text { Hospital }\end{array}$} & $\begin{array}{r}1 \\
2 \\
3 \\
4 \\
5 \\
6 \\
7 \\
8 \\
9 \\
10\end{array}$ & $\begin{array}{l}2 \\
5 \\
7 \\
5 \\
1 \\
3 \\
1 \\
2 \\
2 \\
1\end{array}$ & $\begin{array}{l}2 \\
5 \\
7 \\
9 \\
1 \\
4 \\
1 \\
5 \\
6 \\
2\end{array}$ & $\begin{array}{l}2 \\
5.7 \\
9.1 \\
7.3 \\
1.6 \\
5.5 \\
2.0 \\
4.4 \\
4.9 \\
2.9\end{array}$ & $\begin{array}{l}0.7 \\
2.1 \\
1.7 \\
0.6 \\
1.5 \\
1.0 \\
0.6 \\
1.1 \\
0.9\end{array}$ & $\begin{array}{l}0.61 \\
1.84 \\
2.10 \\
0.59 \\
2.33 \\
0.97 \\
2.35 \\
2.78 \\
1.81\end{array}$ \\
\hline & \multirow[t]{2}{*}{ Total } & 29 & 42 & 43.4 & & 15.38 \\
\hline & & & & & $0.4 \sigma$ & $=3.9$ \\
\hline
\end{tabular}

* Analysis of pedigrees published in the British Medical Research Council (10). 
a detailed analysis of the data derived from the two London hospitals. These data are quite consistent with those cited on the 122 families investigated in detail.

\section{Comment}

The suggestion that an hereditary susceptibility underlies the familial incidence of rheumatic fever, is not, of course, new. A study of the literature shows that several attempts have been made to examine the familial incidence of rheumatism in genetic terms. The results, however, have in no instance been conclusive, chiefly because satisfactory genetic methods had not been applied to the data.

Some workers have based their views on a study of family pedigrees. The difficulty with this approach is that most matings in any pedigree are usually of no critical importance for analytical purposes. Even an extensive pedigree does not obviate the necessity of special study of the critical cases.

Another practice has been to add all families together, regardless of parentage. The results of such computations cannot be interpreted significantly, inasmuch as the expectations are so different in families of negative parents as compared with families with one or both parents positive, that an estimate of the agreement between genetic theory and observations cannot be made.

A third practice among investigators interested in the hereditary aspects of the disease consists in adding together all cases, regardless of the size of the families, and treating the total as a unit for comparison. This procedure is not permissible for studies on rheumatic fever because of the way in which the data are collected. On any genetic basis the frequency of rheumatic children should be smaller for the offspring of negative parents than it is for progeny having one or both parents positive. However, much, if not all, of the data on the familial incidence is gathered from among the children in attendance at a cardiac clinic. Consequently, the families used in such a study will necessarily have at least one rheumatic sibling. All summaries will, therefore, show that all families of one sibling only will be rheumatic, regardless of the presence or absence of the disease in the parents. This source of error is also present in families of larger size, but its magnitude de- creases rapidly as the size of the family increases. Such a selection does not necessarily vitiate the results because it is possible to introduce a simple correction for these omitted cases (15). It must be done separately, however, for each size of family.

Our data, which were also selected from a children's cardiac clinic, were therefore corrected for this factor. Lack of recognition of this source of error may account for the failure of some previous investigators to arrive at definite conclusions from their genetic studies. Much of the published data on this disease were not compared with our results because the summaries of the data could not be separated into components of parental diagnosis or family size or both. Selection of families from members of an adult rheumatic clinic would not need this correction for size of family. An attempt to make such a study proved futile since the progeny of such families was invariably small.

The possibility of inadvertent bias in the selection of the original sample so as to favor the interpretation of genetic transmission has to be considered. It would be quite possible that unknown selective factors might have been operative in any small sample, and perhaps even in the average of a larger series. It would be expected, however, that any large number of individual family groups would show widely different values for the deviation from theory if selective factors were involved. In Table IX, in the last column, the deviation from theory is given for each of 23 samples of parental type and family size (not including families of one sibling only). In no case is it as large as 2 , and in only three cases does it exceed 1.3. It is evident then that this factor is not operative in the 122 families studied.

The demonstration of the mechanism of heredity in rheumatic fever makes it possible to prepare tables of predictions of the probable occurrence of the disease in the progeny of a given mating (with the reservation already stated regarding the limitations of our analysis to families from the lower income groups for New York City environment). Table XIII includes a sample of the types of matings that occur with some frequency. Here it may be seen that if one child has the disease, both parents transmit it, whether 
TABLE XIII

Table of prediction for rheumatic siblings in families of certain matings

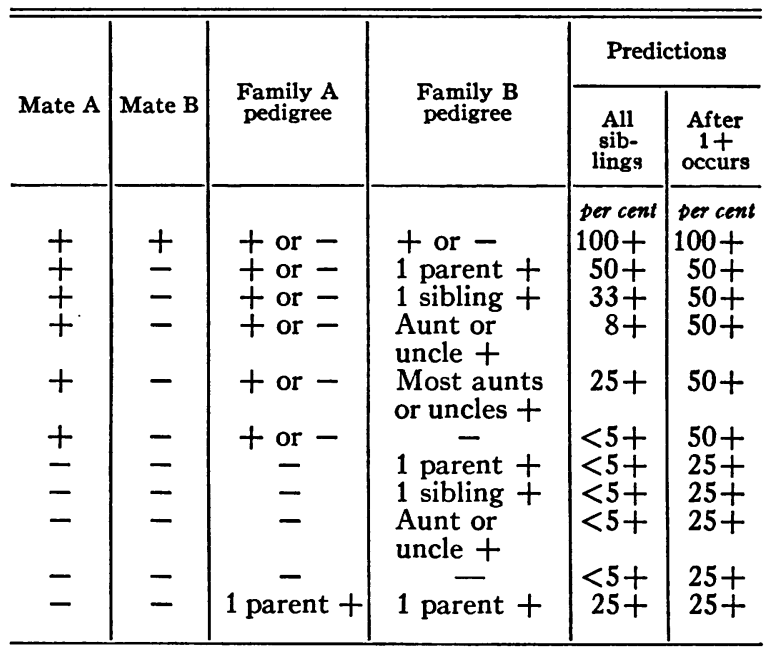

$<$ less than.

they show it or not, and that the subsequent incidence in the family will be 25 per cent, 50 per cent, or 100 per cent, depending on whether neither, one, or both parents have rheumatic fever. If prediction is to be made before the birth of any sibling, the incidence of rheumatic fever in the population must be considered. We have assumed this figure to be less than 10 per cent. A more detailed consideration of the genetic phases of this investigation is now in preparation.

\section{GENERAL DISCUSSION}

We are cognizant of certain possible inaccuracies inherent in the material which has been subject to analysis. Although these families have been under close and exact observation for a period of years, the nature of the disease itself has made the problem a difficult one. Our incomplete knowledge of the etiology and epidemiology of rheumatic fever has required us to make certain assumptions which may prove to be unwarranted. However, on the basis of our present knowledge, accepted diagnostic criteria, and modern genetic methods of analysis, the observations presented will be discussed.

One important contribution of genetic research to clinical medicine is that it admits of numerical predictions in a given situation so that when alternative hypotheses are being considered, it is possible to make a choice based on the agreement between an observed value and those which would be predicted from the several theories. On the basis of a postulated hereditary mechanism, predictions for progeny of different types of matings may be made.

It would seem fair to conclude from the genetic analysis of our data that the susceptibility for rheumatic fever is transmitted as a single autosomal recessive gene. This may be said with some assurance, since it is based on quantitative agreement between observed incidence and the value predicted from this hypothesis.

A consideration of penetrance 4 is of importance in diseases where hereditary factors play a rôle. Penetrance may be defined as the percentage of hereditarily susceptible individuals which manifests a trait (in this case, rheumatic fever). In general genetics, as well as in the study of many human traits, it is common to find that not all individuals with similar genetic backgrounds show the character or show it fully. When every genetically similar individual expresses the trait, penetrance is said to be 100 per cent. On the other hand, if the penetrance is very low, approaching 0 per cent, it may be very difficult to establish the hereditary mechanism.

In the case of a recessive disease, the best method of estimating penetrance is from the progeny of positive parents. In our series, four families where both parents were positive had 15 siblings. Of these, 13 were rheumatic. Of the remaining two individuals, one is now seven years old and the other is fifteen. The penetrance is, therefore, 86 per cent. We have examined from our general clinic 13 additional siblings in $\mathbf{5}$ similar matings, finding 10 rheumatic; taking all the cases together gives a penetrance of 82 per cent.

The occurrence of even a single exception in the progeny of two positive parents has sometimes been advanced as evidence against the interpretation of recessiveness. From the foregoing discussion, it is apparent that this would be true if penetrance were found to be 100 per cent in the progeny of other types of matings. Our negative cases, therefore, cannot be regarded as unfavorable to the interpretation we have made.

4 We wish to acknowledge our indebtedness to Dr. $\mathrm{H}$. J. Muller for helpful suggestions in the discussion of penetrance. 
The failure of a dominant factor to be expressed in any generation may be attributed to poor penetrance. The high penetrance observed in families of positive parents in these families excludes this possibility for our cases.

From the clinical viewpoint the penetrance of rheumatic fever has greater interest than any other single feature of its genetic pattern. If the penetrance is found to be lower in different geographical localities or economic groups, or following particular changes in the environment, important progress will be possible in the prevention of this disease.

In clinical investigation it would be advisable to select, not a sample of the general population, but a series of subjects whose genetic constitutions are known. The evaluation of the efficacy of proposed treatment would be the ratio of positives in the series compared with the predicted incidence for their known genetic background.

If the incidence of rheumatic fever varies in different geographical localities and is lower among families of the well-to-do, it would not be expected that the mechanism of the hereditary susceptibility would be different but that variation in penetrance is the responsible factor.

A correction for variable penetrance has not been introduced in the table of predictions formulated for rheumatic siblings. Its effect would be to lower slightly the prediction for each mating. Since the ${ }^{i}$ actual incidence of rheumatic fever in the general population is not known, the predictions given would be correct only if the incidence is not more than 10 per cent.

Accepting the hereditary transmission of a susceptibility to rheumatic fever, it is interesting to consider whether every susceptible individual will necessarily develop rheumatic fever, or whether the development of the disease is dependent on other factors. By analogy with other human hereditary diseases, either hypothesis is possible. From what we know of the disease, the latter is more likely, namely, that other contributing factors are involved, such as environment and exposure.

The influence of environment in its relation to the occurrence of rheumatic fever in susceptible individuals, cannot be completely discussed from our studies. Selection from a clinic obviously excluded rheumatic families of the well-to-do where the disease is relatively infrequent. Families living in localities in which the incidence of the disease is believed to be low, are not represented. It is, however, evident from our observations that in these rheumatic families living in New York City, unfavorable environmental conditions were not the determining factor influencing the familial incidence of the disease. The incidence of rheumatic fever in one-third of the families living under relatively favorable environmental conditions was comparable to that observed in two-thirds of the families where the environmental conditions were more unfavorable. (These observations are in accord with the report of the British Medical Research Council (4).)

Should comparable studies of the familial incidence of rheumatic fever in families of the wellto-do, living under more favorable climatic conditions, reveal a diminished incidence of the disease among susceptible individuals of the family, a preventive therapeutic method 'would be available in this disease.

Our observations cannot be said to exclude the factor of contagion. The data secured, however, is not consistent with the expectation of most contagious diseases.

In the study of the spread of tuberculosis in families, Opie (17) found that in families where there are open cases of tuberculosis, contact resulted in twice the number of positive cases as did exposure to latent or negative sputum cases, and the incidence for extra-familial exposure was far less than either.

A comparable analysis of the spread of rheumatic fever in our families reveals that, unlike tuberculosis, no direct relation can be demonstrated between type and source of exposure and resulting disease. The analogy, however, is not strictly comparable since it is based on the assumption that the etiological agent was present in the nasopharynx of rheumatic individuals during activity and possibly carried during quiescence. It is conceivable that the virus may be present in the respiratory passages for only a short time, if at all. Had we been able to culture a virus from these individuals, different results might have been obtained. 
Many observers believe that rheumatic fever may be spread only during a 'respiratory infection preceding rheumatic activity. The comparable incidence of rheumatic activity following "active" and "inactive" exposure, would not support this view. It is reasonable to suppose that the acquisition of rheumatic fever may be dependent on the exposure of the susceptible individual to an etiological agent that is widespread in this geographical environment.

In recent years the view that rheumatic fever is an allergic or immunological response of susceptible individuals to specific or nonspecific agents, has been stressed. The evidence presented of an hereditary susceptibility to rheumatic fever would seem to favor this hypothesis. It must, however, be stated that conclusive evidence in support of this concept has not yet been presented.

\section{SUM MARY}

1. There is presented a consideration of the rôle of environment, contagion and heredity as factors responsible for the familial incidence of rheumatic fever in 112 families, observed over a period ranging from 3 to 18 years.

2. There did not appear to be a direct relation between the environments studied and the incidence of rheumatic fever. One-third of the 112 families lived under relatively favorable environmental conditions, and two-thirds lived under unfavorable environmental conditions. In the former group the incidence of rheumatic siblings was 53 per cent, as compared with 46 per cent in the latter group.

3. There was no direct relation between the type and source of exposure and the resulting activity. The incidence of rheumatic fever following " active exposure," and " inactive exposure" was comparable. Intimate contact ("familial exposure") and casual contact (" extra-familial exposure") were equally effective.

(a) Only 21 per cent of 968 person years of " active exposure" could be related to subsequent rheumatic activity.

(b) In a total of 55 families with rheumatic parents, in 47 per cent, activity followed " active exposure"; in 53 per cent, activity followed " inactive exposure."

(c) In 57 families with non-rheumatic parents, in 57 per cent, activity followed " extra-familial exposure" (casual contact); in 43 per cent, activity followed "familial exposure" (intimate contact).

(d) The interval between "active" or " inactive" exposure and the onset of rheumatism was 1 year in 20 per cent; 2 to 5 years in 49 per cent; and 6 to 11 years in 31 per cent.

4. The 227 rheumatic siblings experienced 588 calendar years of rheumatic activity. Of these years, 159 , or 27 per cent, were simultaneous years of rheumatic activity.

(a) The interval between the related manifestations was: 1 month, 29 per cent; 1 to 2 months, 24 per cent; 2 to 11 months, 47 per cent. Three-fourths of the related manifestations of rheumatic activity were between joint pains and other rheumatic manifestations. One-fourth of the related manifestations were between polyarthritis, carditis and chorea. In 66 per cent the interval between these major manifestations was 2 to 11 months.

5. In 51 families, 59 parents (mother or father) were rheumatic; 44 per cent experienced rheumatic activity during the lifetime of the siblings. In no instance did a negative parent acquire the disease. The incidence of rheumatic siblings was comparable in families with a rheumatic mother or father.

6. Of 112 rheumatic families, 49 per cent had parental rheumatism. In only 28 per cent of the families were parents and pedigree on maternal and paternal sides apparently negative.

(a) Of a total of 468 siblings over the age of 3 years, 48 per cent were rheumatic; 46 per cent males and 54 per cent females.

7. All identical twins cited ( 4 pairs) were alike in having rheumatic fever. Of the 12 pairs of fraternal twins, 5 pairs had similar incidence, i.e., both positive or both negative, and 7 pairs had dissimilar incidence.

8. A genetic analysis of the data corrected for size of family gave agreement between observed and expected values.

(a) For children of 58 pairs of negative parents, the observed incidence was 94 , the expected value 88 .

(b) For children of 37 positive mothers, the observed incidence was 90 , the expected value 86 . 
(c) For children of 29 positive fathers, the observed and expected incidence were respectively 29 and 27.9.

(d) The hereditary mechanism involved was a single autosomal recessive gene. Dominance, involving one or more genes, and recessives involving two or more genes, as well as sex linkage were all excluded.

\section{CONCLUSION}

1. These studies indicate that there is an hereditary factor distributed among the population which makes the bearer susceptible to rheumatic fever. This factor is transmitted as a single autosomal recessive gene.

2. The exact rôle of environment and contagion in the acquisition of the disease by susceptible individuals cannot be determined from these studies.

3. Hereditary susceptibility would seem to determine the familial incidence of rheumatic fever, but may not necessarily be the sole condition essential for the development of the disease.

\section{BIBLIOGRAPHY}

1. Paul, J. R., and Salinger, R., The spread of rheumatic fever through families. J. Clin. Invest., 1931, 10, 33.

2. Paul, J. R., Harrison, E. R., Salinger, R., and DeForest, G. R., The social incidence of rheumatic heart disease. A statistical study in New Haven school children. Am. J. M. Sc., 1934, 188, 3.

3. Medical Research Council: Social conditions and acute rheumatism, Great Britain. Special Report Series No. 114, London, 1927.

4. Reports on Public Health and Medical Subjects, Number 44: Acute'Rheumatism in Children in its Relation to Heart Disease. Ministry of Health, London, 1927.

5. Miller, Reginald, The influence of environment on rheumatic infection in childhood. Lancet, 1928, 1, 1005.

6. Irvine- Jones, E., Acute rheumatism as a familial disease. Am. J. Dis. Child., 1933, 45, 1184.

7. Draper, G., Studies in human constitution. IV. He- redity and environment-the disease makers. Am. J. M. Sc., 1926, 171, 803.

8. Cheadle, W. B., The various manifestations of the rheumatic state as exemplified in children and early life. Lancet, 1889, 1, 821.

9. Roberts, J. A. F., and Thomson, W. A. R., An inquiry into the family incidence of acute rheumatism. Ann. Eugenics, 1934, 6, 3.

10. St. Lawrence, W., The family association of cardiac disease, acute rheumatic fever and chorea. A study of 100 families. J. A. M. A., 1922, 79, 2051.

11. Criteria for the Classification and Diagnosis of Heart Disease. New York Tuberculosis and Health Association, Hoeber, New York, 1928.

12. McPhedran, F. M., and Opie, E. L., The spread of tuberculosis in families. Am. J. Hyg., 1935, 22, 565.

13. Coburn, A. F., The Factor of Infection in the Rheumatic State. Williams and Wilkins Co., Baltimore, 1931.

14. Wilson, M. G., Ingerman, E., DuBois, R. O., and Spock, B. McL., The relation of upper respiratory infections to rheumatic fever in children. I. The significance of hemolytic streptococci in the pharyngeal flora during respiratory infection. J. Clin. Invest.; 1935, 14, 325.

Wheeler, G. W., Wilson, M. G., and Leask, M. M., Idem. III. The seasonal bacterial flora of the throat in rheumatic and non-rheumatic children. J. Clin. Invest., 1935, 14, 345.

15. Hogben, L., Nature and Nurture. W. W. Norton Co., New York, 1933.

Genetic analysis of familial traits. Single gene substitutions. J. Genetics, 1931, 25, 97.

Ibid., Double gene substitutions with special reference to hereditary dwarfism. J. Genetics, 1932, 25, 211.

Ibid., Matings involving one parent exhibiting trait determined by single recessive gene substitution with special reference to sex-linked conditions. J. Genetics, 1932, 25, 293.

Factorial analysis of small families with parents of undetermined genotype. J. Genetics, 1932, 26, 75.

16. Levit, S., The problem of dominance in man. J. Genetics, 1936, 33, 411.

17. Opie, Eugene L., Present concepts of tuberculous infection and disease; their principles and application. Am. Rev. Tuberc., 1935, 32, 617. 